\title{
Performance of NiCrAlY Coatings Deposited by Oxyfuel Thermal Spraying in High Temperature Chlorine Environment
}

\author{
K.A. Habib, M.S. Damra, J.J. Carpio, I. Cervera, and J.J. Saura
}

\author{
(Submitted April 7, 2014; in revised form June 9, 2014; published online July 24, 2014)
}

\begin{abstract}
A microcrystalline Ni-22Cr-10Al-1Y (wt.\%) coating was deposited on AISI 304 stainless steel by the oxyfuel thermal spray technique. The deposited coating was subjected to heat treatment to improve the microstructure characteristics and its corresponding high-temperature properties. The isothermal high-temperature corrosion behavior at 650 and $700{ }^{\circ} \mathrm{C}$ in synthetic air and in the presence of $1 \% \mathrm{Cl}_{2}$ was investigated using thermogravimetric analysis, $x$-ray diffraction, and scanning electron microscopy with energy-dispersive $x$-ray spectroscopy. The results indicated that the deposited NiCrAIY coating possessed acceptable oxidation-corrosion resistance at $650{ }^{\circ} \mathrm{C}$ owing to the formation of extensive amounts of the protective oxide of $\mathrm{Cr}_{2} \mathrm{O}_{3}$; $\mathrm{NiO}$ and a lesser amount of a $\mathrm{Cr}_{1.12} \mathrm{Ni}_{2,88}$ metallic phase are also formed. At $700{ }^{\circ} \mathrm{C}$, the coating lost its protective characteristic because of the excessive consumption of thermodynamically stable phases by oxidation-chlorination process. In this case, the steel base and the coating were attacked by chlorine during the exposure time; the mass gain of the NiCrAIY coating was slightly higher and provided only a limited protection up to $11 \mathrm{~h}$; thereafter, breakdown of the layer of oxides occurred and this is attributed to the formation of non-protective oxides mainly $\beta-\mathrm{Fe}_{2} \mathrm{O}_{3}$ and $\mathrm{Fe}_{21.33} \mathrm{O}_{32}$ and the depletion of chromium.
\end{abstract}

Keywords high-temperature degradation, NiCrAlY coating, oxychlorination, oxyfuel thermal spray technique

\section{Introduction}

Several technological problems appear in power plants using bio-mass and municipal waste as fuel. These include high temperature corrosion via penetration of corrosive gases through the scale and/or corrosion and erosion of underling substrate via corrosive salts. Solutions to these problems on low cost substrate materials in combination with tailored coating become technically and economically attractive (Ref 1).

MCrAlY coating $(\mathrm{M}=\mathrm{Ni}$ or/and $\mathrm{Co}$ ) deposited by thermal spraying techniques is widely used in the petroleum sector, in components of industrial gas turbines and aircraft engines and in other applications in which high thermal and mechanical loads have to be supported. The protective feature is so important that about $75 \%$ of all hot components in industrial and aircraft engines are coated (Ref 2,3).Due to the requirement of enhanced power-out of energy plants (Ref 4), there is urgent demand for stable MCrAlY coating with improved longterm performance, as the inlet temperature is increased.

The good protection against high-temperature oxidation and corrosion provided by MCrAlY overlays is attributed to the

K.A. Habib, M.S. Damra, J.J. Carpio, I. Cervera, and J.J. Saura, Industrial Systems Engineering and Design, University JAUME I, Castellón, Spain. Contact e-mail: razzaq@esid.uji.es.

formation of dense and adherent alumina and/or chromia scales (Ref 5, 6). These coatings involve the formation at high temperatures of protective $\mathrm{Cr}_{2} \mathrm{O}_{3}$ and $\mathrm{Al}_{2} \mathrm{O}_{3}$; the protective effect of $\mathrm{Cr}_{2} \mathrm{O}_{3}$ is limited to around $1000{ }^{\circ} \mathrm{C}$, as volatile $\mathrm{CrO}_{3}$ is formed at this temperature, whereas protection by $\mathrm{Al}_{2} \mathrm{O}_{3}$ is effective at higher temperatures $(\operatorname{Ref} 7,8)$.

Adding chromium and/or nickel to iron improves the alloy's resistance to chlorination attack. For this, nickel and nickelbased alloys and coatings are widely used in chlorinecontaining environments. Such coatings offer protection not only against oxygen and nitrogen from the intake air environment but also to a certain extent against attack by fuel or air impurities, such as sulfur $\left(\mathrm{SO}_{2}\right.$ or $\left.\mathrm{SO}_{3}\right)$, chlorine (from maritime and combustion environments), and liquid deposits (sulfates) (Ref 9).

Despite the homogeneous nature of thermally sprayed MCrAlY coatings, they always contain some oxides and porosity at splat boundaries (Ref 10,11 ) which form an interconnected network through the whole coating (Ref 12).

High-temperature corrosion caused by combustion environments is usually accelerated by hot corrosion and gaseous aggressive species such as chlorine and sulfur in combination with oxygen. In oxidizing environments, chlorine accelerates oxidation by mechanism of active oxidation (Ref 13,14$)$. If active oxidation occurs, even small amounts of chlorine circulating through the coatings may cause severe damage to coatings themselves and especially may reduce the bonding strength of the coatings. On the other hand, if the transport of chlorine compounds through coatings is slow, the coatings might maintain their shielding capability.

In $\mathrm{Cl}_{2}$ environment, the partial pressure of $\mathrm{Cl}_{2}$ may be significant near oxides layer (Ref 11). Therefore, solid and 
gaseous metal chlorides can be formed according to the reaction $\mathrm{M}(\mathrm{s})+x / 2 \mathrm{Cl}_{2}(\mathrm{~g}) \rightarrow \mathrm{MCl}_{x}(\mathrm{~s}, \mathrm{~g})$. A comparison of the Gibbs free energies of formation for the different divalent chlorides at $600{ }^{\circ} \mathrm{C}$ shows the highest negative values for $\mathrm{CrCl}_{2}$ $(-286.0 \mathrm{~kJ} / \mathrm{mol})$ followed by $\mathrm{FeCl}_{2}(-232.1 \mathrm{~kJ} / \mathrm{mol})$ and $\mathrm{NiCl}_{2}(-174.2 \mathrm{~kJ} / \mathrm{mol})$ (Ref 15$)$. The energies are very negative, so metals will react with chlorine and according to these data a less reactive behavior is expected for nickel than for iron and chromium. The solid chlorides formed have considerable equilibrium vapor pressures $p_{\mathrm{v}}\left(\mathrm{Me}_{x} \mathrm{Cl}_{y}\right)$ and evaporate continuously according to the following equation: $\mathrm{MCl}_{x}(\mathrm{~s}) \rightarrow \mathrm{MCl}_{x}(\mathrm{~g})$. Metal chlorides can be formed leading to extreme corrosion rates owing to porous non-protective oxide scales and a spongy metal subsurface zone by selective "leaching" of alloying elements (Ref 9).

The formation of oxides and spinel of nickel, aluminum, and chromium contributed to the development of high temperature corrosion resistance of this coating. However, better understanding of the high temperature corrosion performance of such coating is needed in order to establish the mechanism of high temperature corrosion in the aggressive environments.

In previous works (Ref 16, 17), the effectiveness of OF thermal spray technique to improve the tribological behavior and oxidation protection of stainless steels at $850{ }^{\circ} \mathrm{C}$ was proven with a coating system composed of a Ni-Al alloy bond coat and a ceramic topcoat. In a more recent work (Ref 18), it was shown that NiCrAlY thermally sprayed by the OF thermal spray technique provides good oxidation resistance to AISI 304 and AISI 316 stainless steels for temperatures as high as $1000{ }^{\circ} \mathrm{C}$ for $50 \mathrm{~h}$.

The aim of this work was to study the high-temperature corrosion behavior of NiCrAlY coatings deposited by the oxyfuel (OF) thermal spray technique exposed to an oxidationchlorination environment. The analysis includes environmental conditions needed to form protective layers and the conditions that can cause breakdown of oxides layers in an oxidationchlorination atmosphere. The oxides growth at the two studied temperatures is studied in order to get a better understanding of the oxidation-chlorination behavior.

\section{Experimental Procedure}

AISI 304 stainless steel, specimens of $20 \times 10 \times 1.2 \mathrm{~mm}^{3}$, was used as substrates. Specimens were grit blasted with corundum particle of $99.6 \mathrm{wt} . \%$ purity and $0.53-\mathrm{mm}$ mean particle size, using an air pressure of $0.4 \mathrm{MPa}$, incidence angle of approximately $45^{\circ}$, and a gun-to-substrate distance of $130 \mathrm{~mm}$. The surface was then cleaned and degreased using acetone within an ultrasonic bath. The average surface roughness was $5.1 \pm 0.5 \mu \mathrm{m}$ and the mean roughness depth, defined as the vertical distance between the highest peak and deepest valley, was $28.3 \pm 2.4 \mu \mathrm{m}$.

A commercially available $\mathrm{Ni}-22 \mathrm{Cr}-10 \mathrm{Al}-1 \mathrm{Y}$ powder produced by Praxair Surface Technologies-TAFA (Ni-343) with an average particle size of $28 \mu \mathrm{m}$ was deposited on all the sample faces by a Castodyn CDS-8000 flame spray gun made by
Castolin Eutectic, with particles velocity around $300 \mathrm{~m} / \mathrm{s}$ and maximum temperature of $3200{ }^{\circ} \mathrm{C}$. Table 1 shows the parameters of the thermal spraying process.

Preparation of the top surface of the NiCrAlY coatings samples was achieved by grinding it with 240, 400, and 800 grade $\mathrm{SiC}$ in that order to obtain a flat and smooth surface; and finally was ultrasonically cleaned with acetone for $15 \mathrm{~min}$.

Prior to the oxidation-chlorination test, the NiCrAlY-coated specimens were subjected to a heat treatment at $1100{ }^{\circ} \mathrm{C}$ for $4 \mathrm{~h}$ as detailed in Ref 18 to improve the microstructure of the coatings by reducing the porosity and therefore increasing the oxidation resistance.

Isothermal tests at 650 and $700{ }^{\circ} \mathrm{C}$ were performed on NiCrAlY-coated specimens. Samples were heated in a thermobalance (TGA 92-16, Setaram) using synthetic air plus $1 \% \mathrm{Cl}_{2}$ from room temperature to 650 and $700{ }^{\circ} \mathrm{C}$ at a rate of $40 \mathrm{~K} /$ $\min$. They were maintained at these temperatures for $24 \mathrm{~h}$ and then cooled to room temperature at $40 \mathrm{~K} / \mathrm{min}$.

The OF thermally sprayed coatings were characterized using $\mathrm{x}$-ray diffraction (XRD) and scanning electron microscopy (SEM) with energy-dispersive $\mathrm{x}$-ray spectroscopy (EDS).

\section{Results and Discussion}

\subsection{Thermogravimetry Experiments on NiCrAlY at 650 and $700^{\circ} \mathrm{C}$}

Figure 1 shows that after $24 \mathrm{~h}$ at $650{ }^{\circ} \mathrm{C}$ the plot of the weight gain per unit area $\Delta W / S$ versus time $(t)$ assumed a parabolic shape with a rate constant of $2.809 \times 10^{-5}\left[\mathrm{mg}^{2} \cdot\left(\mathrm{mm}^{-4} \cdot \mathrm{s}^{-1}\right)\right]$, calculated according to the equation:

$(\Delta W / S)^{2}=k_{\mathrm{p}} t$

At this temperature, the weight gain (oxidation rate) is relatively low and no sharp changes in the oxidation course can be observed after $24 \mathrm{~h}$; at the end of the test, no external signs of corrosion damage (spallation and cracks) were observed on the surface of the specimen.

At $700{ }^{\circ} \mathrm{C}$, the corrosion kinetics obeys a parabolic law in the initial stage because the weight gain due to oxidation is the dominant process; after $11 \mathrm{~h}$, a second stage occurs, where the behavior becomes linear because oxides formed cannot afford enough protection because the chlorination process occurs (Ref 19). At this temperature, corrosion proceeds in two stages: an incubation period exhibiting a low corrosion rate, followed by accelerated corrosion attack. The incubation period is related to the formation of a protective oxide scale. Initiation of accelerated corrosion attack is believed to be related to the breakdown of the protective oxide scale.

\subsection{XRD Analysis of NiCrA/Y Coatings at 650 and $700^{\circ} \mathrm{C}$}

The XRD patterns obtained from the surface of the OF thermally sprayed NiCrAlY sample after $24 \mathrm{~h}$ at $650{ }^{\circ} \mathrm{C}$

Table 1 Parameters of thermal spray process

\begin{tabular}{lcccc}
\hline Sample & $\begin{array}{c}\text { Preheating } \\
\text { strokes }\end{array}$ & $\begin{array}{c}\text { Distance } \\
(\mathbf{m m})\end{array}$ & $\begin{array}{c}\text { NiCrAIY coat } \\
\text { strokes }\end{array}$ & $\begin{array}{c}\text { Coat thickness } \\
\text { (average) }(\boldsymbol{\mu m})\end{array}$ \\
\hline AISI 304 & 1.2 & 150 & 9 & 186.5 \\
pressure Bar & Neutral \\
\hline
\end{tabular}


(Fig. 2) give evidence of the presence of stable $\mathrm{Cr}_{2} \mathrm{O}_{3}, \mathrm{NiO}$ phases and $\mathrm{Cr}_{1.12} \mathrm{Ni}_{2.88}$ metallic phase.

After $11 \mathrm{~h}$ at $700{ }^{\circ} \mathrm{C}$, surface products were identified by XRD. The major phases observed are as follows: $\mathrm{Fe}_{21.33} \mathrm{O}_{32}$, $\mathrm{Cr}_{1.3} \mathrm{Fe}_{0.7} \mathrm{O}_{3},\left(\mathrm{Fe}_{0.6} \mathrm{Cr}_{0.4}\right)_{2} \mathrm{O}_{3}$ in the oxidized coating, as well as minor peaks relative to $\beta-\mathrm{Fe}_{2} \mathrm{O}_{3}$ and $\mathrm{AlFeO}$ 作 The presence of iron in all phases formed indicates that $\mathrm{Fe}$ ions have diffused through the entire coating from the substrate base metal.

\subsection{SEM Surface Analysis}

The surface morphology of the coating after oxidationchlorination at $650{ }^{\circ} \mathrm{C}$ for $24 \mathrm{~h}$ is presented in Fig. 4. From Fig. 4(a), it can be seen that no cracks or spallation of the oxide scales of the NiCrAlY coating after exposure have occurred. As can be seen from Fig. 4(b) and a corroborated by EDS analysis, three main phases were formed at this temperature (1) a lighter dispersed phase in the form of dotted blocky nodules with a

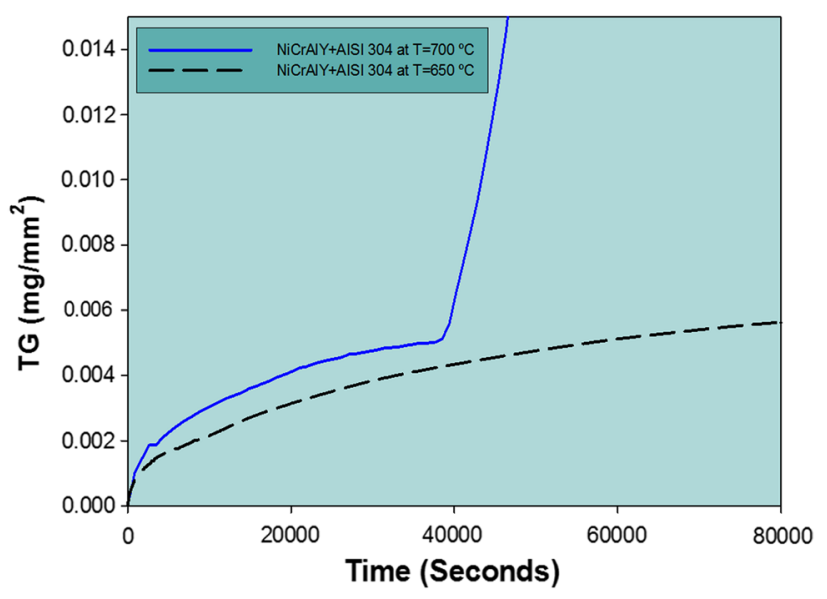

Fig. 1 Isothermal corrosion test of flame thermal sprayed NiCrAlY coat deposited on AISI 304 stainless steel at 650 and $700{ }^{\circ} \mathrm{C}$ in $1 \%$ $\mathrm{Cl}_{2}$ environment for 24 and $11 \mathrm{~h}$, respectively

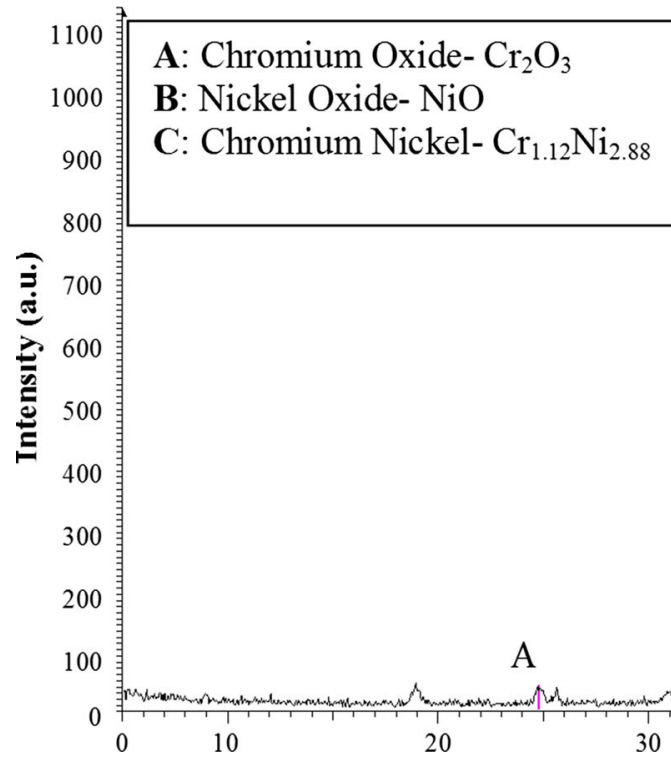

composition (wt. $\%$ ) of $72.96 \% \mathrm{Ni}, 22.40 \% \mathrm{O}, 4.54 \% \mathrm{Cr}, 0.17 \%$ $\mathrm{Al}$, and $0.19 \% \mathrm{Cl}$; (2) a darker phase in the form of spherical blocks with a composition of $49.58 \% \mathrm{Cr}, 24.85 \% \mathrm{O}, 19.81 \%$ $\mathrm{Cl}, 4.76 \% \mathrm{Ni}, 0.64 \% \mathrm{Al}$, and $0.36 \% \mathrm{Y}$; and (3) extensive gray zones with a mean composition of $30.77 \% \mathrm{Ni}, 30.77 \% \mathrm{O}$, $26.96 \% \mathrm{Cr}, 11.07 \% \mathrm{Al}, 0.35 \% \mathrm{Y}$, and $0.07 \% \mathrm{Cl}$.

SEM micrographs showing the surface morphology of the coating are depicted in Fig. 5. The micrographs indicate typical splats morphology for all deposited coating after $24 \mathrm{~h}$ at $700{ }^{\circ} \mathrm{C}$; cracks and spallation of the oxide scales are observed. It can also be seen that microstructure of the coating is formed by a combination of ridges and nodules, (Fig. 5b, c, and d) and that between the nodules, there are smooth patches with clearly marked cracks on the surface. The presence of these cracks could explain how chlorine and oxygen directly accessed the substrate metal.

EDS analysis of the phase in the upper part of Fig. 5(b) gives the following elemental composition (wt.\%): $18.1 \% \mathrm{O}, 8.3 \% \mathrm{Cl}, 24.58 \% \mathrm{Fe}, 0.67 \% \mathrm{Al}, 34.35 \% \mathrm{Cr}$, and $4 \%$ $\mathrm{Ni}$; these results revealed the degradation of the NiCrAlY coating. Figure 5(d) shows a magnification of this zone which has a general elemental composition of $52.05 \% \mathrm{Cr}, 30.44 \% \mathrm{O}$, $11.46 \% \mathrm{Fe}, 3.29 \% \mathrm{Cl}, 1.56 \% \mathrm{Ni}$, and $1.2 \% \mathrm{Al}$. Figure 5(e) shows a nodule of NiCrAlY coating; a punctual analysis of this part indicates the following elemental composition: $34.08 \% \mathrm{Cr}$, $33.32 \% \mathrm{Fe}, 30.38 \% \mathrm{O}, 1.31 \mathrm{Cl}$, and $0.77 \% \mathrm{Ni}$. The morphology of the nodule is tetragonal as seen in Fig. 5(f). The high content of $\mathrm{Fe}$ and $\mathrm{O}$ confirms the results obtained by XRD (no protective iron oxides have been formed).

\subsection{Cross-Section Analysis}

Figure 6 shows a general SEM image of the cross-section of the NiCrAlY deposited on AISI 304 stainless steel after exposure to synthetic air plus $1 \% \mathrm{Cl}_{2}$ at $650{ }^{\circ} \mathrm{C}$ for $24 \mathrm{~h}$. EDS analysis shows that the main elements present (wt.\%) are $\mathrm{O}$ (29\%), $\mathrm{Cr}(22.41 \%), \mathrm{Al}(10.5 \%)$, and $\mathrm{Ni}(32.4 \%)$ and a very low amount of $\mathrm{Cl}(0.52 \%)$ and $\mathrm{Fe}(0.08 \%)$. The presence of the main elements could confirm that protective oxides have formed, as shown from XRD results 


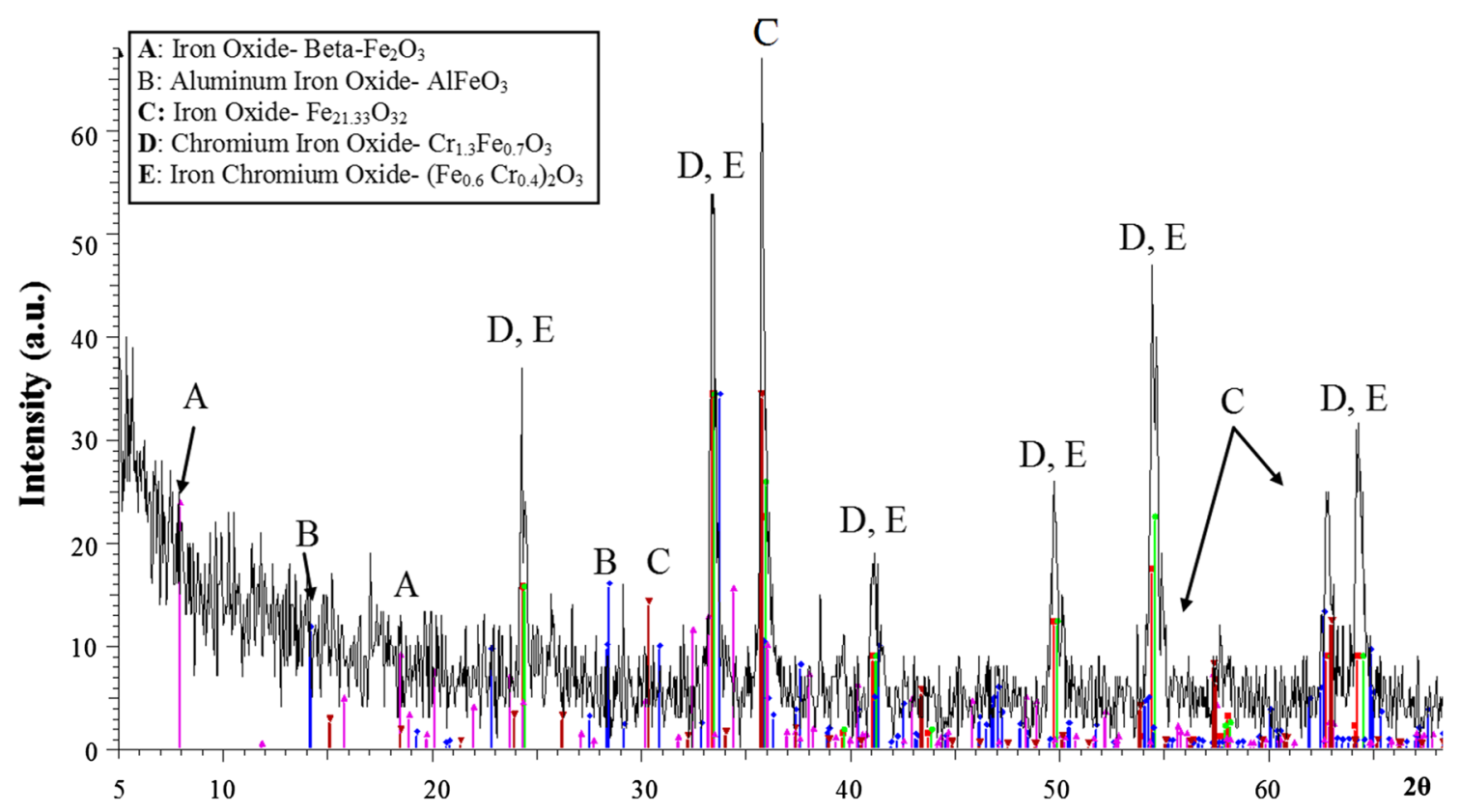

Fig. 3 XRD pattern for NiCrAlY deposited on AISI 304 stainless steel oxidized in $\mathrm{Cl}_{2}$ environment at $700{ }^{\circ} \mathrm{C}$ for $11 \mathrm{~h}$
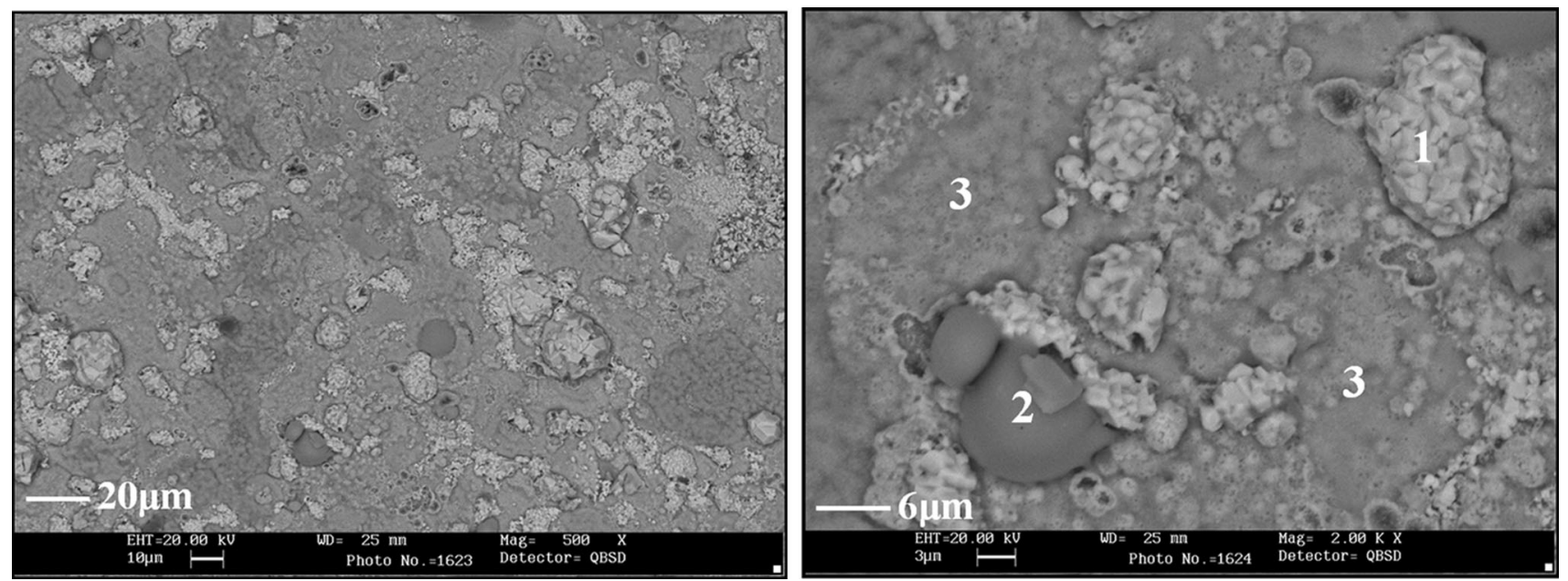

Fig. 4 SEM surface morphology of NiCrAlY coating after oxidation at $650{ }^{\circ} \mathrm{C}$ in $1 \% \mathrm{Cl}_{2}$

From XRD results, only protective oxides products were detected at the surface of the coating. Neither internal attack of the coating nor attack on the substrate base metal was observed.

Figure 7 shows that the oxide top layer present on the $\mathrm{NiCrAlY}$ coating at $650{ }^{\circ} \mathrm{C}$ consisted of two different overlying films (duplex oxide scale); the chemical composition of the inner film scale identified by EDS (wt.\%) was 46.09\% O, $40.46 \% \mathrm{Al}, 9.42 \% \mathrm{Ni}$, and $4.04 \% \mathrm{Cr}$. The analysis of the outer scale indicated that drastic consumption of aluminum (14.74\%) and enrichment of nickel (22.41) and chromium (22\%) occurred; the proportion of oxygen detected was $40.85 \%$. The high aluminum content in the coating is the reason not only for the formation of protective $\mathrm{Al}_{2} \mathrm{O}_{3}$ near the surface of the coating, but also the formation of $\mathrm{Ni}-\mathrm{Cr}$ rich oxide on the surface that could be formed during the very beginning of the exposure at high temperature. The $\mathrm{Al}_{2} \mathrm{O}_{3}$ scale was established beneath the initially formed $\mathrm{Ni}-\mathrm{Cr}$ rich oxide, which usually called transient oxide.
The SEM micrograph and elementals mapping of a crosssection of the oxidized specimen at $650{ }^{\circ} \mathrm{C}$ after $24 \mathrm{~h}$, (Fig. 8), show that the coating was able to stop the attack of chlorine because of the encircled and interconnected $\mathrm{Al}_{2} \mathrm{O}_{3}$ and $\mathrm{Cr}_{2} \mathrm{O}_{3}$, (dark zones in the micrograph) network surrounding the boundaries of $\mathrm{Cr}-\mathrm{Ni}$ metallic splats (light zones in the micrograph). The EDS mappings from the cross-section are consistent with the results obtained from XRD superficial analysis which showed that scale is formed by $\mathrm{NiO}$, protective $\mathrm{Cr}_{2} \mathrm{O}_{3}$, and the $\mathrm{Cr}_{1.12} \mathrm{Ni}_{2.88}$ metallic phase.

The $\mathrm{Al}_{2} \mathrm{O}_{3}$ phase surrounding $\mathrm{Cr}-\mathrm{Ni}$ metallic splats is responsible for improving the oxidation resistance of the coating, because the formation of $\mathrm{Al}_{2} \mathrm{O}_{3}$ can hinder the diffusion of nickel and chromium from inside the splat to the surface and thus prevent the growth of $\mathrm{Cr}_{2} \mathrm{O}_{3}$ and $\mathrm{NiCr}_{2} \mathrm{O}_{4}$, which is attributed to the low diffusion coefficients of nickel and chromium along the grain boundary of the metallic phase: the diffusion coefficient of aluminum along the grain boundary 


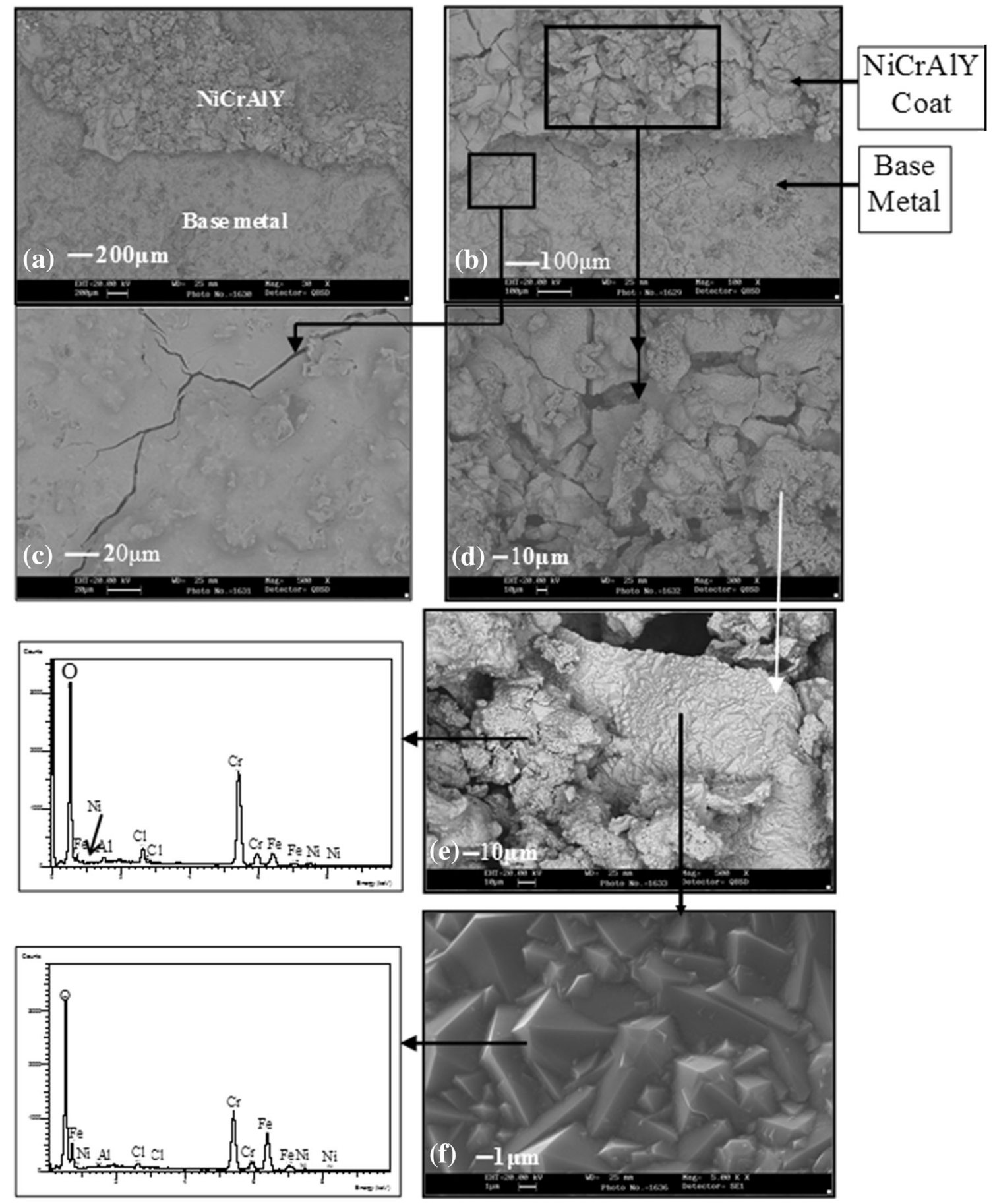

Fig. 5 SEM micrographs with EDS analysis of NiCrAlY deposited on AISI 304 after $11 \mathrm{~h}$ at $700{ }^{\circ} \mathrm{C}$, showing surface morphology and composition at different locations

of nickel and chromium is greater than that of nickel and chromium (Al: $2.8 \times 10^{-4} \mathrm{~m}^{2} / \mathrm{s}, \mathrm{Cr}: 6.9 \times 10^{-11} \mathrm{~m}^{2} / \mathrm{s} ; \mathrm{Ni}$ : $\left.2.53 \times 10^{-10} \mathrm{~m}^{2} / \mathrm{s}\right)($ Ref 20$)$. The formation of $\mathrm{Al}_{2} \mathrm{O}_{3}$ during oxidation-chlorination process can hinder the growth of the grains of the coatings during crystallization because it covers the grain boundary. The previous discussion leads us to state that the performance of the OF thermally sprayed NiCrAlY coating on austenitic stainless steel in an air plus $\mathrm{Cl}_{2}$ atmosphere at $650{ }^{\circ} \mathrm{C}$ was good owing to the formation of this continuous chromium and aluminum-rich oxide double layer of approximately $2-\mu \mathrm{m}$ thick and the internal oxidation of the coating.

Figure 9 shows the SEM images and EDS analysis (elemental chemical composition) of the cross-section of the NiCrAlY-coated sample oxidized until the breakdown happened at $700{ }^{\circ} \mathrm{C}$. It seems that the coat was strongly damaged and the corrosion spread toward the base metal. The NiCrAlY coating was penetrated by chlorine via splats boundaries, and was massively attacked; causing many cracks and interfaces between the base metal and the corrosion products layer. In 

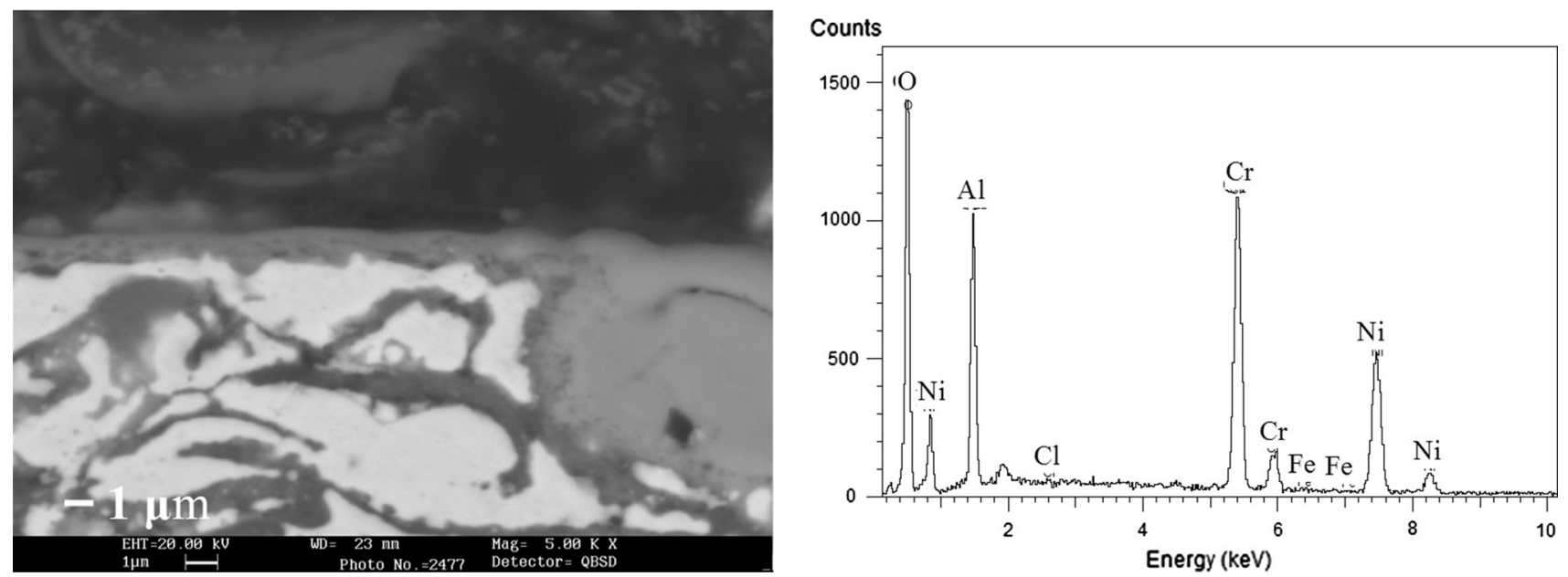

Fig. 6 SEM micrograph with EDS analysis of the cross-section of NiCrAlY coat deposited on AISI 304 corroded at $650{ }^{\circ} \mathrm{C}$ in $1 \% \mathrm{Cl}_{2}$ during $24 \mathrm{~h}$

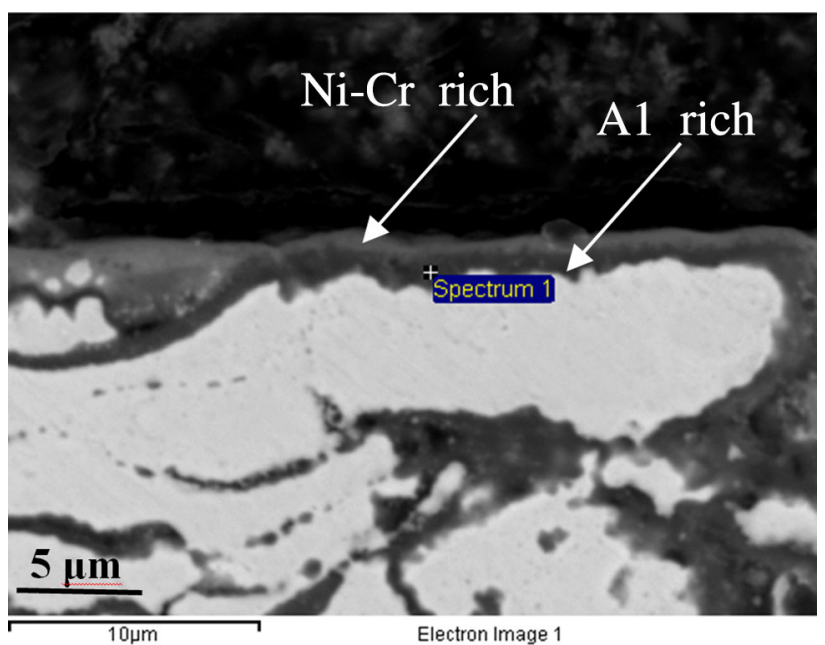

Fig. 7 Cross-section of duplex scale formed on the top of oxidized NiCrAlY coating after $24 \mathrm{~h}$ at $650^{\circ} \mathrm{C}$

Fig. 9(a), it seems that the metal substrate has been reached by chlorine and oxygen as can be deduced from the EDS analysis which shows chlorine content as high as $30 \%$ and an oxygen content of $23.65 \%$. Figure 9(b) illustrates the morphology of the corrosion layer formed in the metal-coating interface, which is porous and severely cracked; EDS analysis showed that the corrosion layer contains metal elements, mainly nickel $(30.16 \%)$ and chromium (18.67\%) from the coating as well as iron $(10.23 \%)$ from the metal substrate, but it also contains important amounts of chlorine (19.32\%) and oxygen $(21.32 \%)$. These two layers (oxides formed on the metal substrate and the corrosion products of the NiCrAlY coating) suffered from attack by aggressive species like chlorine and oxygen. Figure 9(c) shows an intermediate part which corresponds to the bulk of corrosion layer; the EDS analysis showed that this layer is formed mainly by nickel $(75.49 \%)$ and chromium $(20.29 \%)$ from the sprayed NiCrAlY coating and by small amounts of oxygen $(2.27 \%)$, iron $(1.82 \%)$, and chlorine $(0.07 \%)$. Figure $9(\mathrm{~d})$ shows the corrosion products formed on the outer surface, which seems to be heterogeneous in morphology as well as in chemical composition. Elemental analysis with EDS showed that this layer is formed mainly by two types of compounds: one of them conserves high contents from the original elements of the NiCrAlY coating $(75.49 \% \mathrm{Ni}$ and $20.29 \% \mathrm{Cr}$ ) and has very low contents of oxygen $(2.27 \%)$, iron $(1.82 \%)$, and chlorine $(0.07 \%)$; the other compound contains much smaller amounts of nickel $(10.93 \%)$ and chromium $(3.63 \%)$ and the amounts of oxygen $(26.78 \%)$, iron $(50.13 \%)$, and chlorine $(7.86 \%)$ are markedly increased.

The damage to the NiCrAlY coating at $700{ }^{\circ} \mathrm{C}$ for $11 \mathrm{~h}$ is due to the effects of chlorine. One of these effects is that it changes the morphology of the coating by the evaporation of metal chlorides leading to more rapid attack even if the amount of chlorides formed is negligible (Ref 21).

X-ray mapping for NiCrAlY coated on AISI 304 stainless steel at $700{ }^{\circ} \mathrm{C}$, Fig. 10, indicates that the corrosion layer formed has different chemical compositions. In the most external part, aluminum and oxygen are detected, but high amounts of chlorine and iron are also found. In the whole layer nickel and iron are present, but higher concentrations of both elements are detected mainly in the central part of the layer. Diffusion of iron from substrate to the entire coating is also evident.

Important amounts of nickel, iron, and oxygen are also present near the substrate, which means that nickel-iron oxides have formed near the metal substrate.

$\mathrm{X}$-ray mapping shows the absence of chromium in the entire scale; it can be explained by chromium volatilization or might be the EDS signal for $\mathrm{Cr}$ is overlapped with oxygen or other element so that $\mathrm{Cr}$ was not recognized.

$\mathrm{X}$-ray mappings show that chlorine is present in the entire coating; the major role of $\mathrm{Cl}_{2}$ is to destroy the protective oxide scale as well as to produce the internal voids by means of the chlorination-oxidation reactions. $\mathrm{Cl}_{2}$ will dissolve into $\mathrm{Cr}_{2} \mathrm{O}_{3}$ and increase the cation-vacancy concentration and accelerate oxidation, or it will attack the alloy substructure and form metal chlorides (Ref 22). This leads to the formation of a porous (Fe, $\mathrm{Ni}$ ) oxide scale, which is not protective, and the chlorine cycle of corrosion is not hindered. As a result, all the chromium of the coating is depleted, and chlorine may reach the steel through the interconnected pores and voids formed. 


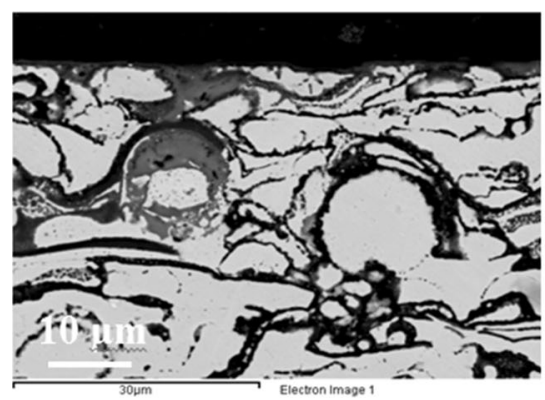

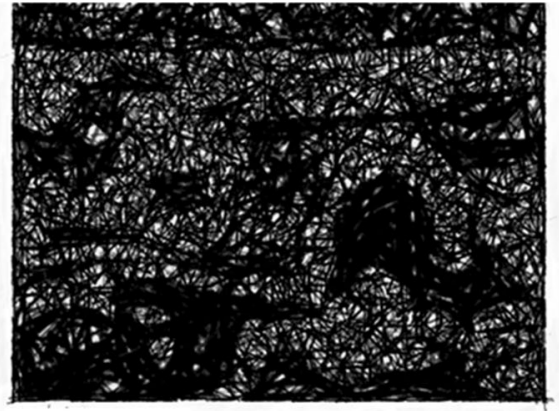

$\mathrm{O}-\mathrm{K} \alpha$

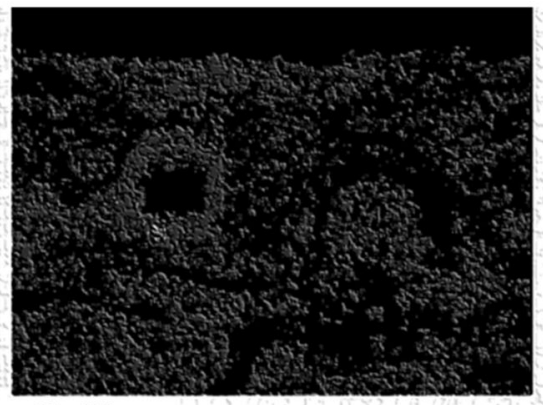

$\mathrm{Cr}-\mathrm{K} \alpha$

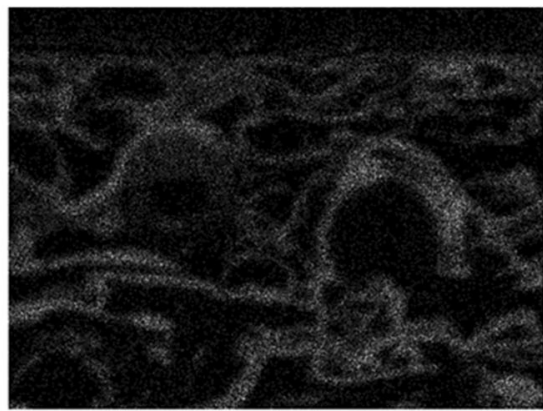

$\mathrm{Al}-\mathrm{K} \alpha$

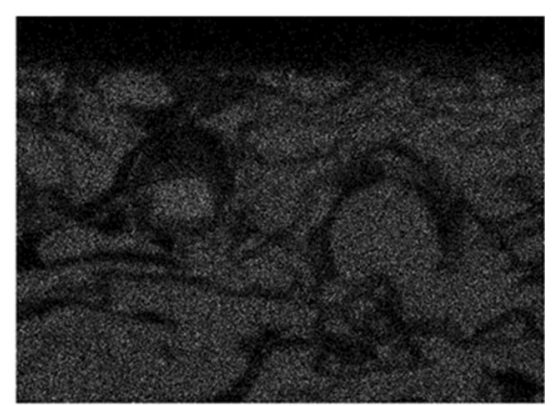

$\mathrm{Ni}-\mathrm{K} \alpha$

Fig. 8 Elements mapping of cross-section of NiCrAlY coating after $24 \mathrm{~h}$ at $650{ }^{\circ} \mathrm{C}$ in oxidation-chlorination atmosphere

As the protective feature of alumina scale has been deteriorated, oxygen and chlorine can easily penetrate into the coating and cause the formation of internal oxide and chromium oxychloride. This internal oxide and chromium oxychloride will accelerate the consumption of beneficial elements, and consequently speed up the corrosion process.

The oxidation-chlorination process can be described in detail as follows:

When NiCrAlY coating is exposed to an oxidizing environment at high temperature, the elements will gradually oxidize to thermodynamically stable oxides and form metal oxides. These oxides $\left(\mathrm{Cr}_{2} \mathrm{O}_{3}\right.$ and $\left.\mathrm{Al}_{2} \mathrm{O}_{3}\right)$ provide a barrier for further diffusion of oxygen and other gaseous species. However, chlorine has the ability to penetrate the protective oxides. $\mathrm{Cl}_{2}$ diffuses through the oxide, presumably through pores and cracks to the coating and coating metal interface, where it reacts with the metal alloy to form metal chloride.

Due to the high oxygen affinity of $Y$, it can be supposed that almost the whole amount of $Y$ contained in the NiCrAlY powder will be oxidized during the flame-spraying process. The formation of Y oxides in the NiCrAlY coating during the deposition process would lead to a reduction in the amount of $Y$ as a metallic component, and this means that only a small amount of $Y$ is left to be oxidized during the high-temperature oxidation. Many authors reported on the transport of reactive elements ions in the alloy during oxidation, leading to the nucleation of oxide particles rich in RE in the oxide scale (Ref 23).

It is well known that RE additions prevent the formation of interfacial voids presumably by blocking outward diffusion of $\mathrm{Al}$ in the scales. RE may influence the collapse of dislocations loops at interfacial-vacancy aggregates, which maintains the interfacial cohesion and prevents cavity formation (Ref 24, 25). Segregation of sulfur contamination could also influence the formation of the interfacial voids. Because no sulfur could be detected as a segregant at the metal-scale interface, it was assumed that the formation of the voids was due to the outward transport of aluminum and that the yttrium influence on the scale formation was minimal. In this work, $\mathrm{Y}$ has not been detected by EDS and XRD.

Chlorine alters the defect structure of the scale and increasing the diffusion coefficient of chloride ions by dissolving in the oxide scale (Ref 26). At ionic lattice sites, singly charged chloride ions may replace doubly charged oxygen ions. Considering charge and site balance, we have the following reaction ( $\operatorname{Ref} 27,28)$ :

$\mathrm{Cl}_{2}(\mathrm{~g})+\mathrm{O}_{n} \rightarrow 2 \mathrm{Cl}_{\mathrm{o}}+\mathrm{V}_{\mathrm{M}} \rightarrow 1 / 2 \mathrm{O}_{2}(\mathrm{~g})$

This reaction increases the concentration of cation vacancies. The vacancies tend to precipitate as voids resulting in pitting and spalling of the scale. The oxide scale cannot effectively hinder diffusion of the chloride ions through the scale to the matrix.

At the coating-metal interface, a very low oxygen potential exists $\left(\mathrm{O}_{2}\right.$ is consumed to produce metal oxides), at which volatile metal chlorides such as $\mathrm{FeCl}_{3}$ and $\mathrm{CrCl}_{2}$ are thermodynamically stable. The $\mathrm{Cl}_{2}$ may react with metal according to the Reactions 1 to form metal chlorides:

$\mathrm{M}_{(\mathrm{S})}+\mathrm{Cl}_{2}(\mathrm{~g}) \rightarrow \mathrm{MCl}_{2}(\mathrm{~s})$

Metal chloride has high vapor pressure at coating-metal interface and continuous evaporation may take place (Reaction 3):

$\mathrm{MCl}_{2}(\mathrm{~s}) \rightarrow \mathrm{MCl}_{2}(\mathrm{~g})$.

The volatile metal chloride may diffuse through the oxidized coating. The oxygen concentration increases with increasing distance from the base metal, leading to oxidation of the metal chloride to solid metal oxide, according to the following reactions: 


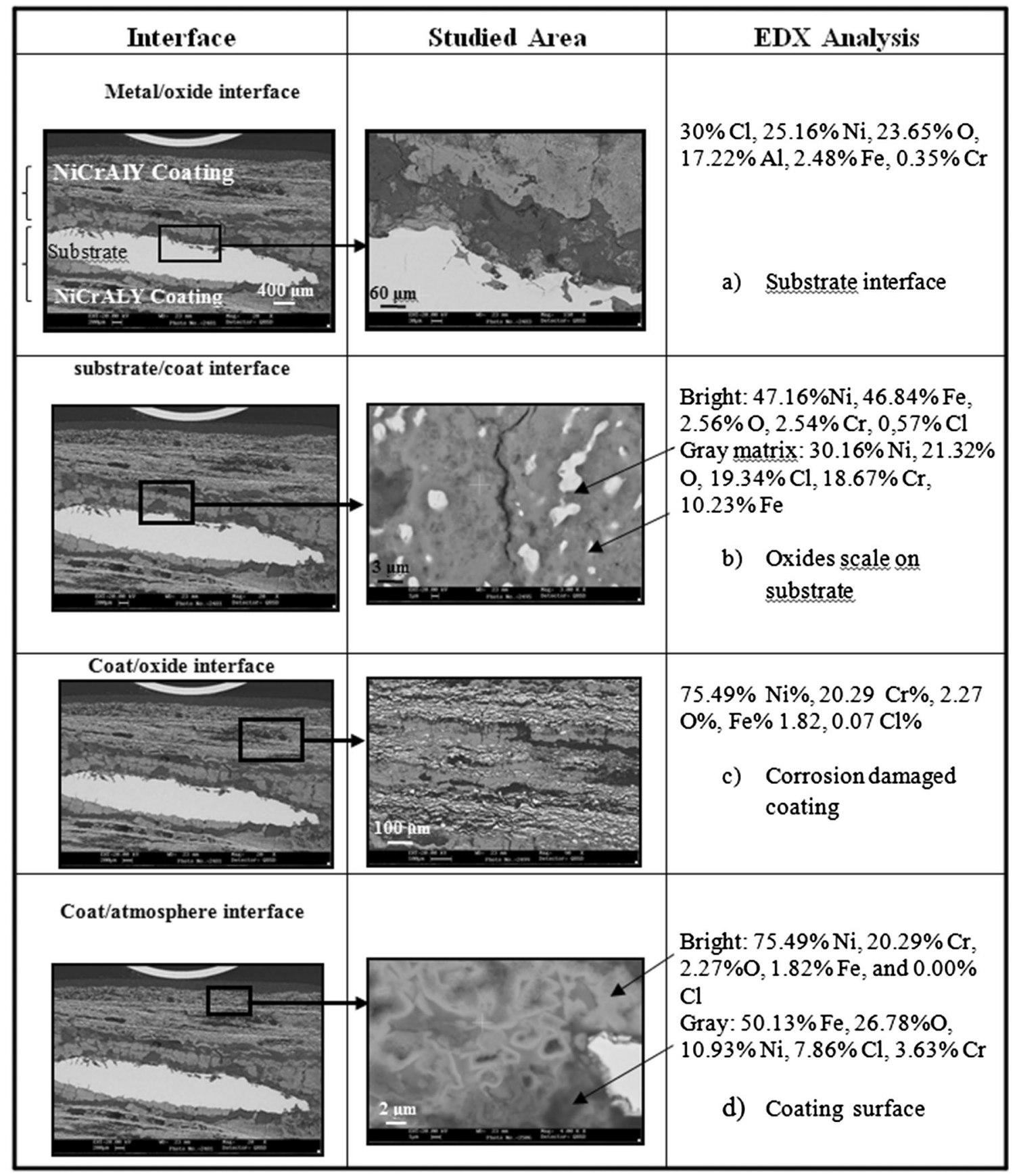

Fig. 9 SEM cross-section morphology with EDS analysis of NiCrAlY coat deposited on AISI 304 at $700{ }^{\circ} \mathrm{C}$ for $11 \mathrm{~h}$ in $1 \% \mathrm{Cl}_{2}$

$\mathrm{MCl}_{2}(\mathrm{~g})+2 \mathrm{O}_{2}(\mathrm{~g}) \rightarrow \mathrm{M}_{3} \mathrm{O}_{4}(\mathrm{~s})+3 \mathrm{Cl}_{2}(\mathrm{~g})$,

$2 \mathrm{MCl}_{2}(\mathrm{~g})+3 / 2 \mathrm{O}_{2}(\mathrm{~g}) \rightarrow \mathrm{M}_{2} \mathrm{O}_{3}(\mathrm{~s})+2 \mathrm{Cl}_{2}(\mathrm{~g})$.

The resulting oxides that precipitate from this gas phase reaction form a very loose metal-oxide layer, providing no protection by further attack. Thus, chlorine corrosion is often governed by linear corrosion rate. These oxides formed in this process are porous and non-protective. If oxidation of gaseous metal chlorides occurs near the metal surface, some of the chlorine released in the oxidation process will diffuse back to the base metal-oxide interface and the oxidation process will proceed.
According to Reactions 5 and 6, chlorine is released and can diffuse to the bulk gas or back to coating surface, and thus the cycle is formed. A graphical presentation of the corrosion mechanism is shown in Fig. 11. This cycle provides a continuous transport of metals away from the coating surface toward higher oxygen partial pressure with little net consumption of chlorides. The net reaction is thus

$4 \mathrm{M}(\mathrm{s})+3 \mathrm{O}_{2}(\mathrm{~g}) \rightarrow 2 \mathrm{M}_{2} \mathrm{O}_{3}(\mathrm{~s})+2 \mathrm{Cl}_{2}(\mathrm{~g})$.

Gas diffusion through the scale is believed to be the ratecontrolling step in the corrosion process. 


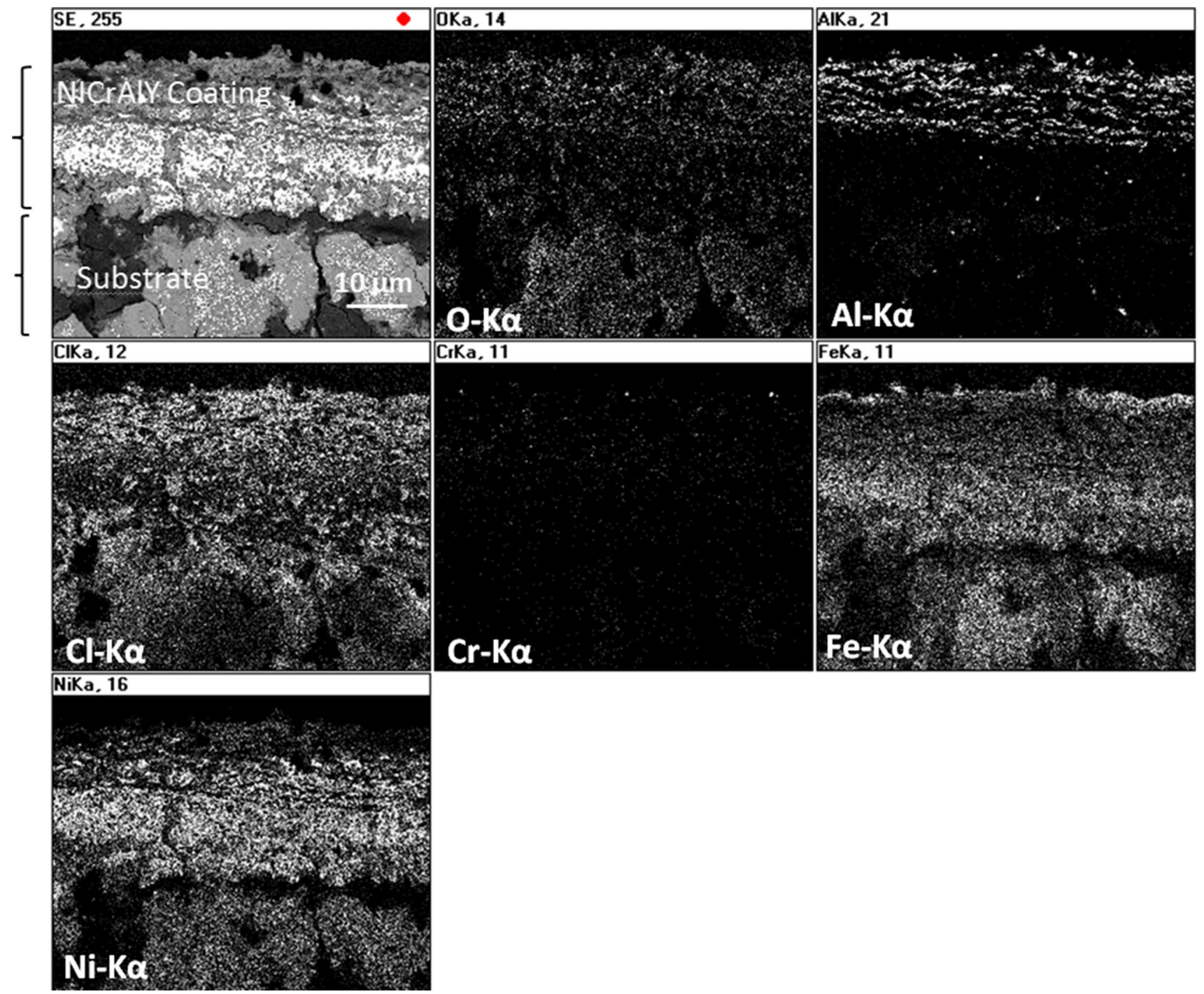

Fig. 10 X-ray mappings along the cross-section on NiCrAlY-coated AISI 304 in chlorine atmosphere during $11 \mathrm{~h}$ at $700{ }^{\circ} \mathrm{C}$

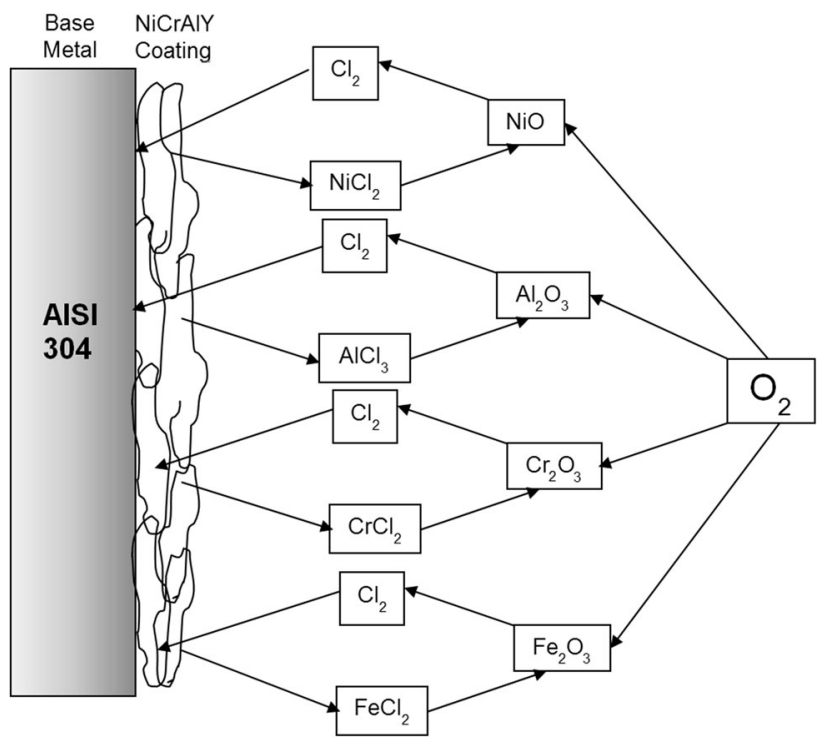

Fig. 11 Flow chart of oxychlorination of NiCrAlY coating on AISI 304
The oxide scale formed on NiCrAlY reacts with chlorine; the displacement reactions are

$$
\begin{aligned}
& \mathrm{NiO}(\mathrm{s})+\mathrm{Cl}_{2}(\mathrm{~g}) \rightarrow \mathrm{NiCl}_{2}(\mathrm{~g})+1 / 2 \mathrm{O}_{2}(\mathrm{~g}), \\
& \mathrm{Al}_{2} \mathrm{O}_{3}(\mathrm{~s})+3 \mathrm{Cl}_{2}(\mathrm{~g}) \rightarrow 2 \mathrm{AlCl}_{3}(\mathrm{~g})+3 / 2 \mathrm{O}_{2}(\mathrm{~g}), \\
& \mathrm{Cr}_{2} \mathrm{O}_{3}(\mathrm{~s})+3 \mathrm{Cl}_{2}(\mathrm{~g}) \rightarrow 2 \mathrm{CrCl}_{3}(\mathrm{~g})+3 / 2 \mathrm{O}_{2}(\mathrm{~g}) .
\end{aligned}
$$

Transformation of metallic oxides into metallic chlorides in high temperature environments occur again giving place to further deterioration of oxide scale.

When chlorine has reached the metal surface, it reacts with metals forming metal chlorides. Gibbs free energies for metal chloride formation are strongly negative, which means that metal chlorides can form. The partial pressures of gaseous metal chlorides at 650 and $700{ }^{\circ} \mathrm{C}$ are significant and continuous evaporation of metal chlorides takes place in an open system. Gibbs free energies for metal chloride formation (and partial pressures of metal chlorides) at different temperatures (ranging from 550 to $850{ }^{\circ} \mathrm{C}$ ) for $\mathrm{Fe}, \mathrm{Ni}, \mathrm{Cr}$, and $\mathrm{Al}$ are presented in Table 2, extracted from results given but other authors (Ref 29-33). 
Table 2 Formation reactions, Gibbs free energy for metal chlorides and oxides at different temperatures

\begin{tabular}{lllll}
\hline & \multicolumn{4}{c}{$\Delta \boldsymbol{G}(\mathbf{k J} / \mathbf{m o l})$} \\
\cline { 2 - 5 } Reactions & $\mathbf{6 0 0}^{\circ} \mathbf{C}$ & $\mathbf{6 5 0}^{\circ} \mathbf{C}$ & $\mathbf{7 0 0}^{\circ} \mathbf{C}$ & $\mathbf{7 5 0}^{\circ} \mathbf{C}$ \\
\hline Chlorination of metals & & & & \\
$\mathrm{Fe}+\mathrm{Cl}_{2}=\mathrm{FeCl}_{2}(\mathrm{l})$ & -232 & -227 & -222 & -218 \\
$\mathrm{Cr}+\mathrm{Cl}_{2}=\mathrm{CrCl}_{2}(1)$ & -286 & -280 & -275 & -268 \\
$\mathrm{Ni}+\mathrm{Cl}_{2}=\mathrm{NiCl}_{2}(\mathrm{~s})$ & -174 & -167 & -160 & -153 \\
$\mathrm{Al}+3 / 2 \mathrm{Cl}_{2}=\mathrm{AlCl}_{3}$ & -545 & -540 & -535 & -532 \\
\hline
\end{tabular}

A comparison of the Gibbs free energies of formation of the different divalent chlorides shows that the highest negative values correspond to $\mathrm{CrCl}_{2}$ followed by $\mathrm{FeCl}_{2}$ and $\mathrm{NiCl}_{2}$ (Ref 22, 31). According to these data, a less reactive behavior is expected for nickel than for iron and chromium. The solid chlorides formed have considerable equilibrium vapor pressures $p_{\mathrm{v}}\left(\mathrm{Me}_{x} \mathrm{Cl}_{y}\right)$ and therefore evaporate continuously and diffuse outward to the gas-scale interface.

In can also be seen in Table 2 that Gibbs free energy for $\mathrm{AlCl}_{3}$ formation is also very negative; therefore, this metal chloride can be formed at high temperatures $\left(550-750{ }^{\circ} \mathrm{C}\right)$ under the experimental conditions.

The calculated partial pressures at $650{ }^{\circ} \mathrm{C}$ for oxygen $p \mathrm{O}_{2}=-0.19$ and chloride $p \mathrm{Cl}_{2}=-1.208$ and at $700{ }^{\circ} \mathrm{C}$ for oxygen $p \mathrm{O}_{2}=-0.166$ and chloride $p \mathrm{Cl}_{2}=-1.185$ indicate that iron and chromium chlorides are thermodynamically stable at these pressure conditions at both temperatures and the thermodynamically stable phase for aluminum at these partial pressures is $\mathrm{Al}_{2} \mathrm{O}_{3}$.

Besides, the Gibbs free energies for formation of $\mathrm{Fe}, \mathrm{Cr}, \mathrm{Ni}$, and $\mathrm{Al}$ oxides are given in Table 2. All of these oxides have very negative values of Gibbs free energy indicating that $\mathrm{Fe}_{2} \mathrm{O}_{3}, \mathrm{Fe}_{3} \mathrm{O}_{4}, \mathrm{Cr}_{2} \mathrm{O}_{3}, \mathrm{NiO}_{2}$, and $\mathrm{Al}_{2} \mathrm{O}_{3}$ can form in the range of temperatures in this study. The more negative Gibbs free energy for formation of $\mathrm{Al}_{2} \mathrm{O}_{3}$ can explain the formation of this oxide in the NiCrAlY coating in the experimental conditions at $650{ }^{\circ} \mathrm{C}(\operatorname{Ref} 22,31,33)$.

The actual oxygen and chlorine potentials prevailing at the scale/metal interface will differ a lot from those in the atmosphere, due to the additional reactions between chlorine and metals and between chlorides and oxygen.

Considering that chlorine penetrates into the scale faster than oxygen and enriches at the scale/metal interface, the oxygen pressure at the scale/metal interface will be fixed by the local equilibrium established between the oxides and the metals. In consequence, besides $\mathrm{FeCl}_{2}$ and $\mathrm{CrCl}_{2}, \mathrm{AlCl}_{3}$ becomes stable too; the $\mathrm{Cr}$ and $\mathrm{Al}$ chlorides will rapidly evaporate and diffuse outward through the scale by vapor-phase transport, and are decomposed into oxides again as they reach zones in the scale with higher partial pressures of oxygen. The $\mathrm{CrCl}_{2}$ can then be oxidized to form $\mathrm{Cr}_{2} \mathrm{O}_{3}$ and the $\mathrm{Cl}_{2}$; this latter diffuses inward to attack again the metal at the scale/metal interface. If the temperature is higher, volatilization of $\mathrm{CrCl}_{2}$ is preponderant and the scale can be $\mathrm{Cr}$ depleted (Ref 22, 30-34). If oxygen and chlorine pressure are low enough, the $\mathrm{AlCl}_{3}$ is a stable phase and formation of $\mathrm{Al}_{2} \mathrm{O}_{3}$ is hindered. Therefore, $\mathrm{Al}$ will be selectively removed from the coating as chloride according to the following reaction (Ref 30$)$ :

$2 \mathrm{Al}(\mathrm{s})+3 \mathrm{Cl}_{2(\mathrm{~g})}=2 \mathrm{AlCl}_{3(1, \mathrm{~g})}$.
The $\mathrm{AlCl}_{3}$ will diffuse outward due to its high volatility and be transferred into aluminum oxides subsequently at the outer part of the coating (scale). In these circumstances, aluminum moves toward to the outer surface of the coating.

Moreover, at these partial pressures and due to the enhanced iron and chromium activity and enriched chlorine, strong outward transport of $\mathrm{FeCl}_{2}$ and $\mathrm{CrCl}_{2}$ will occur leading to rapid transport of iron as iron oxide layer due to decomposition of the chloride to oxide and depletion of chromium due to high volatilization of $\mathrm{CrCl}_{2}$.

Finally, the enhanced internal penetration rate of oxygen is unlikely to be caused just by solid diffusion in the bulk coating or even by grain boundary diffusion. Instead, several other key factors should be considered. First, the diffusivity and solubility of atomic chlorine dissolved in the coating can be much higher than that of oxygen. In this circumstance, the formation of $\mathrm{AlCl}_{3}$ at the corrosion front is well favored and its outward diffusion will produce a void-rich porous region beneath the surface scale, which can act as open channels for the subsequent fast inward transport of oxygen (Ref 30, 33).

The preformed aluminum oxide is attacked by chlorine at $700{ }^{\circ} \mathrm{C}$ and thus the other metallic elements of the coating can be exposed to corrosive gas environment. The chlorine gas can diffuse into the interface between metal and preformed oxide through the oxide film and then follows the active oxidation steps as described: (1) diffusion of chlorine through preformed aluminum oxide and microdefects of the oxide where the oxygen potential is low, (2) reaction of the chlorine with aluminum in the alloy, (3) formation of the volatile aluminum chloride (Eq 11), (4) diffusion of the volatile aluminum chloride, $\mathrm{AlCl}_{3}$, through defects of the coatings through making cracks or holes due to the high vapor pressure of the volatile metal chloride, (5) formation of chlorine and aluminum oxide from the reaction between aluminum chloride and oxygen, (Eq 9), and (6) transport of some parts of the gaseous aluminum chloride to the bulk gas phase.

In previous investigations (Ref 35), the experimental gas components $\left(\mathrm{O}_{2}\right.$ and $\left.\mathrm{Cl}_{2}\right)$ are shown to be the species with the highest diffusion coefficients. Among these two species, $\mathrm{O}_{2}$ diffuses more rapidly; the diffusion coefficient at $1000 \mathrm{~K}$ for $\mathrm{O}_{2}$ is $1.55 \mathrm{~cm}^{2} / \mathrm{s}$, while at the same temperature $\mathrm{Cl}_{2}$ diffuses with $0.96 \mathrm{~cm}^{2} / \mathrm{s}$ in the gas mixture.

Metal chlorides diffuse more slowly, and differences may be noticed in the diffusion coefficients between species not only as a function of their metallic element, but also as a function of their number of chlorine and oxygen atoms. For a general view of the diffusivities of each species, the following order is developed (species are ordered according to their diffusivities from the fastest to the slowest, Ref 35):

$$
\begin{aligned}
\mathrm{O}_{2} & >\mathrm{Cl}_{2}>\mathrm{CrOCl}_{3} \approx \mathrm{CrO}_{2} \mathrm{Cl}_{2}>\mathrm{NiCl}_{2} \\
& \approx \mathrm{CrCl}_{2}>\mathrm{CrCl}_{3} \approx \mathrm{CrCl}_{4}>\mathrm{AlCl}_{3}>\mathrm{FeCl}_{2} \approx \mathrm{FeCl}_{3} .
\end{aligned}
$$

With this comparison, chromium chlorides and nickel chlorides are shown to be the fastest species among the metal chlorides, followed by the aluminum chlorides, and finally the iron chlorides. At $727^{\circ} \mathrm{C}$, the diffusion coefficients range from $0.823 \mathrm{~cm}^{2} / \mathrm{s}$ for $\mathrm{CrO}_{2} \mathrm{Cl}_{2}$ to $0.451 \mathrm{~cm}^{2} / \mathrm{s}$ for $\mathrm{FeCl}_{3}$. It should be noted that the difference in the diffusivities of the species is accentuated by increasing the temperature.

Active oxidation was responsible for the accelerated corrosion oxidizing environments. The coating and substrate AISI 
304 were prone to chlorine attack in both atmospheres through oxide network at splat boundaries.

Breakdown corrosion at $700{ }^{\circ} \mathrm{C}$ is caused by dissolution of $\mathrm{Cr}_{2} \mathrm{O}_{3}$ and $\mathrm{Al}_{2} \mathrm{O}_{3}$. In addition, corrosive $\mathrm{O}$ and $\mathrm{Cl}$ diffused inward along the grain boundary of the coating. With time increasing, the coating was corroded completely and lost protection rapidly. In fact, its corrosion behavior represents that of the substrate alloy at last stage.

\section{Conclusions}

1. NiCrAlY coating deposited by (OF) thermal spraying shows a severe temperature dependence concerning its corrosion resistance in chlorine plus air environment.

2. The high temperature chlorination resistance of $\mathrm{NiCrAlY}$ coating at $650{ }^{\circ} \mathrm{C}$ for $24 \mathrm{~h}$ has been attributed to the formation of chromium oxides and nickel-chromium at the surface coating, and alumina at the splat boundaries. The oxide scale has been preferentially formed at the splat boundaries due to oxidation of the active elements of the coating. The Ni-Cr metallic-rich phase of the coating mostly remains in the un-oxidized state.

3. At $700{ }^{\circ} \mathrm{C}$ the corrosion behavior reaches the breakdown limit at $11 \mathrm{~h}$. Therefore, the behavior moves from parabolic to linear as a result of the formation of porous and cracked oxides: $\beta-\mathrm{Fe}_{2} \mathrm{O}_{32}, \mathrm{Fe}_{21} \mathrm{O}_{32}$, etc. The EDS study of the cross-section of the degraded samples at $700{ }^{\circ} \mathrm{C}$ indicated that the mechanism of corrosion corresponds to active oxidation due to the selective diffusion of chlorine to the surface with the formation of voids below and the depletion of chromium compounds at the surface.

4. The good resistance of the heat-treated NiCrAlY coating at $650{ }^{\circ} \mathrm{C}$ in a $1 \% \mathrm{Cl}_{2}$ atmosphere suggests that the $\mathrm{OF}$ thermal spraying process can be used as a technological alternative to more expensive vacuum plasma spray and high velocity OF deposition.

\section{References}

1. S. Paul and M.D.F. Harvey, Corrosion Testing of Ni alloy HVOF Coatings in High Temperature Environments for Biomass Applications, J. Therm. Spray Technol., 2013, 22(2-3), p 316-327

2. D.P. Whittle, D. Coutsouradis, P. Felix, H. Fischmeister, L. Habraken, Y. Linblon, and M.O. Speidel, Ed., High Temperature Alloys for Gas Turbines, Applied Science, London, 1978, p 109

3. F. Wang, X. Tian, Q. Li, L. Li, and X. Peng, Oxidation and Hot Corrosion Behaviour of Sputtered Nanocrystalline Coatings of Superalloy K52, Thin Solid Films, 2008, 516(6), p 5740-5747

4. D. Mudgal, S. Sigh, and S. Prakash, Hot Corrosion Behavior of Some Superalloys in a Simulated Incinerator Environment at $900^{\circ} \mathrm{C}, \mathrm{J}$. Mater. Eng. Perform., 2014, 23(1), p 238-249

5. D. Xie, Y. Xiong, and F. Wang, Effect of an Enamel Coating on the Oxidation and Hot Corrosion Behaviour of a HVOF-Sprayed $\mathrm{Co}-\mathrm{Cr}-$ Al-Y Coating, Oxid. Met., 2003, 59(5-6), p 503-516

6. D. Wolfe and J. Singh, Functionally Gradient Ceramic/Metallic Coatings for Gas Turbine Components by High-Energy Beams for High-Temperature Applications, J. Mater. Sci., 1998, 33, p 3677-3692

7. W. Brandl, D. Toma, and H.J. Grabke, The Characteristic of Alumina Scales Formed on HVOF-Sprayed MCrAlY Coatings, Surf. Coat. Technol., 1998, 108(109), p 10-15

8. W. Brandl, H.J. Grabke, D. Toma, and J. Kruger, The Oxidation Behaviour of Sprayed MCrAlY Coatings, Surf. Coat. Technol., 1996, 86(87), p 41-47
9. M. Schutze, M. Malessa, V. Rohr, and T. Weber, Development of Coatings for Protection in Specific High Temperature Environment, Surf. Coat. Technol., 2006, 201(7), p 3872-3879

10. M.A. Uusitalo, P.M.J. Vuoristo, and T.A. Mantyla, High Temperature Corrosion of Coatings and Boiler Steels below Chlorine-Containing Salt Deposits, Corros. Sci., 2004, 46(6), p 1311-1331

11. A. Hernas, M. Imosa, B. Formanek, and J. Cizner, High Temperature Chlorine-Sulfur Corrosion of Heat Resisting Steels, J. Mater. Process. Technol., 2004, 157-158, p 348-353

12. A. Pardo, M.C. Merino, A.E. Coy, F. Viejo, R. Arrabal, and E. Matykina, Corrosion Behaviour of Magnesium/Alumina Alloys in 3.5 wt $\%$ NaCl, Corros. Sci., 2008, 50(3), p 823-834

13. M. Spiegel, Salt Melt Induced Corrosion of Metallic Materials in Waste Incineration Plants, Mater. Corros., 1999, 50(7), p 373-393

14. H.H. Krause and I.G. Wright, Boiler Tube Failure in Municipal Wasteto-Energy Plants, Mater. Perform., 1996, 35(1), p 46-53

15. A. Zahs, M. Spiegel, and H.J. Grabke, Chloridation and Oxidation of Iron, Chromium, Nickel and their Alloys in Chloridizing and Oxidizing Atmospheres at $400-700^{\circ}$ C, Corros. Sci., 2000, 42(6), p 1093-1122

16. K.A. Habib, J.J. Saura, C. Ferrer, and M.S. Damra, Comparison of Flame Sprayed $\mathrm{Al}_{2} \mathrm{O}_{3} / \mathrm{TiO}_{2}$ Coatings: Their Microstructure, Mechanical Properties and Tribology Behaviour, Surf. Coat. Technol., 2006, 201, p 1436-1443

17. K.A. Habib, J.J. Saura, C. Ferrer, M.S. Damra, and I. Cervera,

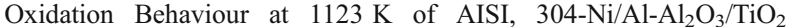
Multilayer System Deposited by Flame Spray, Rev. Metal., 2011, 47(2), p 126-137

18. K.A. Habib, M.S. Damra, J.J. Carpioa, I. Cervera, and J.J. Saura, Oxidation Behaviour of a NiCrAlY Coating Deposited on AISI 304 and AISI 316 Stainless Steels by Flame Thermal Spraying Technique (Oxyfuel OF), Presented at the 8th High Temperature International Conference on Corrosion and Protection of Materials (HTCPM8), Les Embiez-France, May 20-25, 2102

19. G.Y. Lai, High-Temperature Corrosion of Engineering Alloys, ASM International, Materials Park, OH, 1990, p 85-115

20. Y.N. Wua, M. Qin, Z.C. Feng, Y. Liang, C. Suna, and F.H. Wang, Improved Oxidation Resistance of NiCrAlY Coatings, Mater. Lett., 2003, 57, p 2404-2408

21. G. Sorell, The Role of Chlorine in High Temperature Corrosion in Waste-to-Energy Plants, Mater. High Temp., 1997, 14(3), p 207-220

22. C.J. Wang and T.T. He, Morphological Development of Subscale Formation in Fe-Cr-(Ni) Alloys with Chloride and Sulfates Coating, Oxid. Met., 2002, 58(3-4), p 415-437

23. D. Toma, W. Brandl, and U. Köster, Studies on the Transient Stage of Oxidation of VPS and HVOF Sprayed MCrAlY Coatings, Surf. Coat. Technol., 1999, 120-121, p 8-15

24. D. Toma, W. Brandl, and U. Köster, The Characteristics of Alumina Scales Formed on HVOF-Sprayed MCrAlY Coatings, Oxid. Met., 2000, 53(1/2), p 125-137

25. B.A. Pint, Experimental Observations in Support of the DynamicSegregation Theory to Explain the Reactive-Element Effect, Oxid. Met., 1996, 45(1-2), p 1-37

26. B.R. Singh and P. Balk, Oxidation of Silicon in the Presence of Chlorine and Chlorine Compounds, J. Elechtorochem. Soc., 1978, 125(3), p 453-461

27. R. Subramanian, R. Dieckmann, G. Eriksson, and A. Pelton, Model Calculations of Phase Stabilities of Oxide Solid Solutions in Co-FeMn-O System at $1200^{\circ}$ C, Phys. Chem. Solids, 1994, 55(5), p 391-404

28. N. Kanari, D. Mishra, J. Mochón, L.F. Vereja, F. Doit, and E. Allain, Algunos aspectos Cineticos de las Reacciones de Solidos con Cloro, Rev. Metal., 2010, 46(1), p 22-36 (in Spanish)

29. M.A. Uusitalo, P.M.J. Vuoristo, and T.A. Mäntylä, High Temperature Corrosion of Coatings and Boiler Steels Below Chlorine-Containing Salt Deposits, Corros. Sci., 2004, 46, p 1311-1331

30. G. Han and W.D. Cho, High-Temperature Corrosion of $\mathrm{Fe}_{3} \mathrm{Al}$ in $1 \%$ $\mathrm{Cl}_{2} / \mathrm{Ar}$, Oxid. Met., 2002, 58(3/4), p 391-413

31. A. Zahs, M. Spiegel, and H.J. Grabke, Chloridation and Oxidation of Iron, Chromium, Nickel and Their Alloys in Chloridizing and Oxidizing Atmospheres at $400-700^{\circ} \mathrm{C}$, Corros. Sci., 2000, 42, p 1093-1122

32. Y. Yonghua Shu, F. Wang, and W. Wu, Corrosion Behavior of Pure $\mathrm{Cr}$ with a Solid $\mathrm{NaCl}$ Deposit in $\mathrm{O}_{2}$ Plus Water Vapor, Oxid. Met., 2000, 54(5/6), p 457-471 
33. C.J. Wang and C.C. Li, The High-Temperature Corrosion of Austenitic Stainless Steel with a $\mathrm{NaCl}$ Deposit at $850^{\circ} \mathrm{C}$, Oxid. Met., 2004, 61(5/6), p 485-505

34. M.C. Mayoral, J.M. Andrés, J. Belzunce, and V. Higuera, Study of Sulphidation and Chlorination on Oxidized SS310 and PlasmaSprayed Ni-Cr Coatings as Simulation of Hot Corrosion in Fouling and Slagging in Combustion, Corros. Sci., 2006,

48 , p 1319-1336

35. H. Latreche, S. Doublet, and M. Schütze, Development of Corrosion Assessment Diagrams for High Temperature Chlorine Corrosion Part II: Development of "Dynamic" Quasi-stability Diagrams, Oxid. Met., 2009, 72, p 31-65 